\title{
Kajian Teknis dan Ekonomis Distribusi Gas Alam dari FSRU Menuju Superblok
}

\author{
Adhi Muhammad Faris Katili, Ketut Buda Artana, dan A.A.B. Dinariyana D.P. \\ Jurusan Teknik Sistem Perkapalan, Fakultas Teknologi Kelautan, Institut Teknologi Sepuluh Nopember \\ Jl. Arief Rahman Hakim, Surabaya 60111 Indonesia \\ e-mail: ketutbuda@its.ac.id
}

\begin{abstract}
Abstrak-Penggunaan gas alam di Indonesia saat ini didominasi oleh sektor industri dan pembangkit. Badan Pengkaji dan Penerapan Teknologi (BPPT) memproyeksikan dalam rentang 2012-2035 total konsumsi gas bumi di perkirakan akan tumbuh sebanyak $2,2 \%$ per tahun menjadi 2.367 BCF pada tahun 2035. Yang menariknya adalah pertumbuhan penggunaan gas bumi terbesar ada di sektor retail yang pertama adalah rumah tangga $(17,6 \%)$, transportasi $(13,4 \%)$ dan komersial $(3,9 \%)$. Disisi lain pengembangan kawasan yang terintegrasi atau superblok di Indonesia atau Jabodetabek khususnya semakin banyak berkembang namun kawasan superblok saat ini tidak memiliki jaringan gas terpadu. Studi ini membahas tentang menjangkau pasar retail pada LNG, untuk menjawab pertanyaan apakah investasi ini layak untuk direalisasikan? Bagaimana alur distribusi gasnya? Seperti apa desain terminal penerimanya? Secara garis besar penelitian ini terbagi menjadi 2 yaitu kajian keekonomian dan teknis, pada keekonomian menggunakan metode optimasi untuk memilih ukuran kapal yang digunakan dan NPV, PBP, ROI sebagai indikator layak atau tidaknya sedangkan kajian teknis difokuskan pada desain terminal yang ada di Superblok dengan standar yang digunakan adalah NFPA 59A. Hasil dari studi menunjukkan NPV baru bernilai positif jika margin dari penjualan gas yang diambil 6 dollar per mmbtu. Dengan nilai investasi awal sebesar 19,070,000 US\$ dan biaya operasional pertahunya sebesar 1,666,436 US\$ maka investasi ini akan kembali pada tahun ke 8 dengan return of Investment $12 \%$. Kemudian hasil dari mendesain terminal penerima pada salah satu superblok didapatkan luas lahan yang dibutuhkan yang sesuai dengan NFPA 59A adalah $50 \times 50$ meter.
\end{abstract}

Kata Kunci-Small Scale LNG, Mini terminal LNG, Solver, NFPA 59A, kajian teknis, kajian ekonomis.

\section{Pendahuluan}

$\mathrm{G}$ as alam mempunyai peran penting sebagai sumber energi. Indonesia dengan potensi gas buminya pada tahun 2012 mencapai 151 TSCF. Jumlah itu terdiri dari cadangan 103 TSCF cadangan terbukti dan 47 TSCF cadangan potensial. Umumnya sumber daya gas tersebut berada di luar pulau Jawa terutama di Sumatera termasuk Natuna yang nilai cadangannya hampir 56\%, kemudian diikuti oleh Papua (16\%), Kalimantan (11\%), Maluku (10\%), Jawa (8\%) dan Sulawesi (2\%). Kemudian produksi per tahunnya baik gas ikutan (associated) maupun bukan ikutan (non associated) mencapai 3,17 TCF pada tahun 2012. Jika potensi gas itu dibagi dengan produksinya maka Indonesia memiliki cadangan sampai dengan 33 tahun mendatang.
Penggunaan gas alam di Indonesia didominasi oleh sektor industri dan pembangkit, ke depan diharapkan juga digunakan oleh sektor komersial (hotel dan restoran) dan rumah tangga. Badan pengkaji dan penerapan teknologi atau lebih dikenal dengan BPPT memproyeksikan dalam rentang waktu 2012 - 2035, total komsumsi gas bumi di perkirakan akan tumbuh rata-rata sebesar 2,2\% per tahun atau naik mencapai hingga 1,6 kali pada tahun 2035. Penggunaan gas bumi meningkat dari $1.445 \mathrm{BCF}$ pada tahun 2012 menjadi $2.367 \mathrm{BCF}$ pada tahun 2035. Dengan persentase pengguna di sektor industri mencapai $51 \%$ di ikuti oleh pembangkit listrik $33 \%$,lalu sektor transportasi $2 \%$, rumah tangga $1 \%$ dan komersial $1 \%$. BPPT juga memprediksi pertumbuhan penggunaan gas bumi terbesar ada pada sektor rumah tangga dengan pertumbuhan rata-rata sebesar $(17,6 \%)$ per tahun, di ikuti sektor transportasi $(13,4 \%)$, komersial $(3,9 \%)$, pembangkit listrik $(2,8 \%)$ dan industri $(2,9 \%)$ [1]. Proyeksi itu perlu kita tindak lanjuti agar tidak hanya menjadi harapan, belum lama ini pada bulan Oktober tanggal 30 Perusahaan gas negara atau PGN telah menyalurkan gas kepada 137 keluarga di Pasuruan [2]. Ini merupakan salah satu langkah nyata guna merealisasikan penggunaan gas pada sektor rumah tangga walaupun jumlah dari total konsumsinya sangat kecil jika dibandingkan sektor-sektor lainnya. Pengembangan penggunaan gas pada sektor rumah tangga ke depannya akan makin marak, seiring dengan pertumbuhan ekonomi yang tinggi menyebabkan banyaknya pembangunan perumahan superblok di kotakota besar Indonesia. Seperti wilayah Jabodetabek, Surabaya, Medan dan kota-kota besar lainnya.

Pembangunan superblok merupakan salah satu solusi dalam masalah urban city, dengan memaksimalkan lahan yang terbatas dan solusi dalam mengembangkan kota yang lebih efisien dengan konsep one stop living enviroment. Namun ada satu hal yang kurang dikembangkan dari perumahan superblok yaitu sistem aliran gas terpadu. Pembangunan mini scale LNG untuk wilayah superblok cukup menjanjikan untuk dilakukan investasi, tersedianya kawasan komersial (hotel, mal dan restoran) dan perumahan masyarakat kelas menengah ke atas. Diharapkan pembangunan mini scale LNG ini dapat meningkatkan konsumsi gas rumah tangga dengan target pengembangan awal di daerah Jabodetabek. Daerah Jabodetabek memiliki keistimewaan khusus karena dekat dengan Floating Storage and Regasification Unit (FSRU) Jawa barat yang berada di teluk Jakarta dan juga FSRU lampung. FSRU Jawa barat ini telah beroperasi sejak April 2012 dioperasikan oleh PT Nusantara Regas [3]. 


\section{DASAR TEORI}

\section{A. Liquefied Natural Gas (LNG) dan Small Scale LNG}

Liquefied Natural Gas (LNG) merupakan gas alam yang sudah didinginkan pada temperatur dengan kisaran $-161^{\circ} \mathrm{C}$ pada tekanan atmosfer. likuefaksi dapat mereduksi volume gas kurang lebih menjadi 600 kali lebih kecil yang bisa membuat lebih bernilai ekonomis untuk menyimpan gas alam di saat tempat penyimpanan dalam wujud lain tidak tersedia, dan untuk mendistribusikan gas apabila jaraknya sangat jauh penggunaan pipeline menjadi sangat mahal dikarenakan keharusan untuk melakukan pembebasan lahan, atau adanya suatu batasan lain. Likuefaksi menjadikan perpindahan gas alam antar benua menjadi mungkin khususnya dengan digunakannya kapal. Maka dari itu, teknologi LNG menjadikan gas alam bisa tersedia di seluruh dunia.

LNG supply chain terdiri dari eksplorasi dan produksi dari gas alam, likuefaksi, pengangkutan LNG melalui laut, dan penyimpanan LNG, regasifikasi dan pengiriman gas alam menuju ke konsumen [4].

Internasional gas union (IGU) mendefinisikan Small Scale LNG dengan fasilitas likuefaksi dan regasifikasi yang kapasitas nya dibawah 1 MTPA, dan kapal SSLNG merupakan kapal dengan kapasitas angkut dibawah $18,000 \mathrm{~m} 3$. SSLNG dibagi menjadi 2 kategori yaitu wholesale \& Retail. Letak perbedaannya yaitu jika pada wholesale juga melibatkan proses likuefaksi sedangkan retail hanya fokus pada transportasi menuju end user consumption [5].

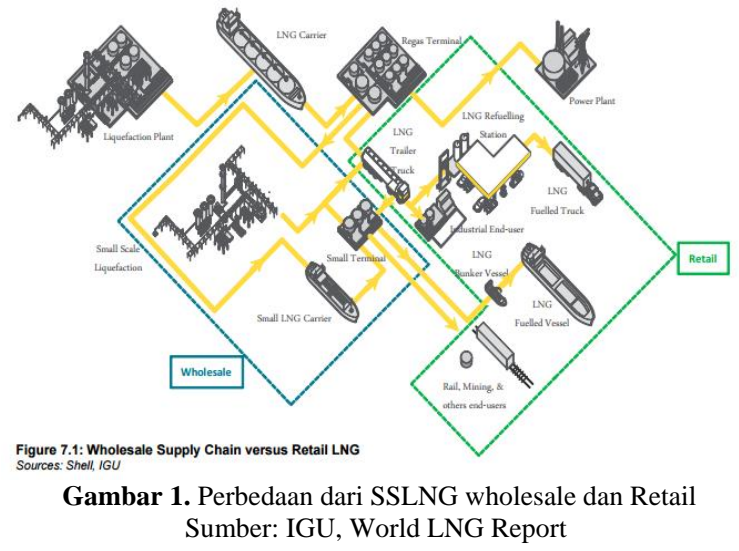

\section{B. Superblok}

Menurut Ridwan Kamil, Superblok merupakan suatu kawasan di konteks urban yang dirancang secara terpadu dan terintegrasi (integrated developement), berdensitas cukup tinggi dalam konsep tata guna lahan yang bersifat campuran (mixed-use). Tidak ada ukuran minimal untuk luasan kawasan superblok, dengan beberapa blok/lot gedung yang dibuat saling terintegrasi dalam suatu konsep masterplan dapat diklaim sebagai superblok[6].

Konsep superblok dirancang agar menjadi kawasan yang mandiri, dimana orang yang hidup didalamnya, dapat tinggal, bekerja dan berekreasi dalam satu lokasi sehingga akan mengurangi bepergian keluar kawasan tersebut, dan dalam arti lain juga menghemat waktu karena mengurangi macet.

\section{Permodelan Alur Distribusi}
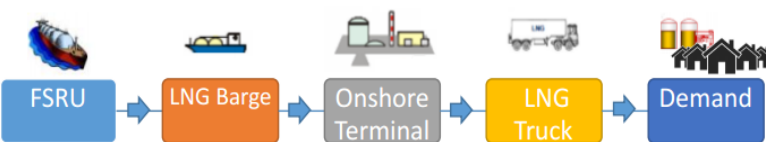

Gambar 2. Lingkup permasalahan yang dibahas

Lingkup permasalahan yang akan dibahas di batasi seperti gambar diatas. LNG yang ada di dalam FSRU kemudian diteruskan dengan LNG barge ke terminal penerima. Di terminal penerima kemudian dipindahkan ke ISO Tank LNG yang kemudian diangkut menggunakan truk untuk dikirim ke tempat permintaan gas (Superblok) setelah Truk LNG sampai di terminal LNG skala kecil kemudian (SSLNG) LNG di dalam ISO Tank dikembalikan ke bentuk gas untuk didistribusikan dengan menggunakan pipa.

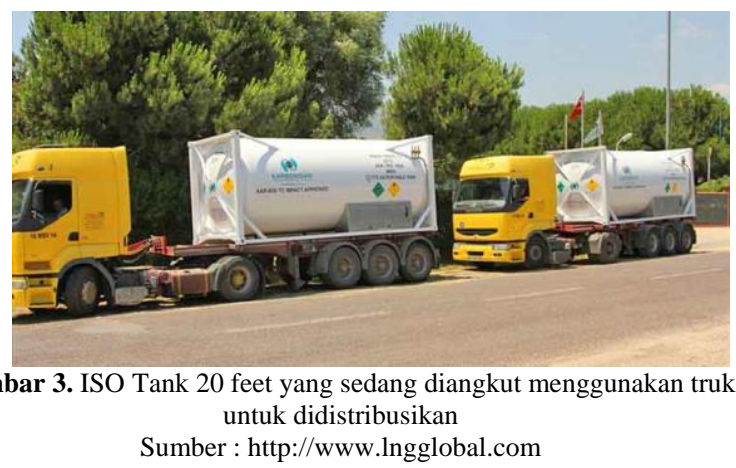

\section{Analisa Kelayakan Investasi}

Analisa kelayakan investasi digunakan untuk mengukur apakah suatu investasi yang akan dilakukan benar-benar dapat memberikan hasil yang menguntungkan atau tidak. Ada banyak cara yang dapat dilakukan untuk mengukur kelayakan suatu investasi, diantaranya adalah NPV (Net Present Value) dan IRR (Internal Rate Return). Sementara untuk mengetahui periode pengembalian suatu investasi dapat menggunakan PBP (Pay Back periods).

\section{E. NFPA 59A}

NFPA 59A adalah standar yang digunakan untuk LNG, standar ini meliputi proses produksi, penyimpanan dan penanganannya [7].

a) Plant Siting and Layout

Standar ini digunakan untuk keperluan desain, lokasi, konstruksi, operasi dan pemeliharaan pada setiap lokasi pencairan gas alam, penyimpanan, pentransferan, penguapan, dan transportasi. Standar ini digunakan untuk semua kontainer tangki penyimpanan LNG termasuk pada penerapan sistem isolasi.

b) Tangki Penyimpanan

Mengatur ketinggian tangki, ketinggian tanggul pelindung tangki, jarak antara dinding bagian dalam dan permukaan dinding bagian luar tangki, dan tingkat ketinggian fluida yang diizinkan pada bagian atas suatu tangki.

c) Fasilitas Bongkar Muat

Mengatur jarak pipa bongkar muat pada jetty, pendinginan pada sambungan pipa, dan jarak antar perlatan bongkar muat.

d) Peralatan Proses

Mengatur tekanan pengaman pada pompa dan kompresor, penanganan terpisah antara kompresor 
BOG dan tangki penyimpanan, penggunaan sistem ventilasi, dan penggunaan katup.

e) Vaporizer

Mengatur klasifikasi panas pada sistem vaporizer, klasifikasi suhu lingkungan, manifolfd vaporizer, pengontrolan unit vaporizer, katup-katup, jarak vaporizer dengan tangki penyimpanan $\mathrm{LNG}$ dan fasilitas lain.

\section{Metodologi}

Penelitian ini dibagi menjadi 2 bahasan utama yaitu kajian keekonomian dan teknis. Ke keekonomian dilakukan terlebih dahulu untuk mengetahui apakah layak atau tidak untuk direalisasikan jika layak maka dilanjutkan untuk mendesain kajian teknisnya.

Kajian ekonomis meliputi perhitungan berapa kebutuhan gas yang dibutuhkan setiap tahunnya, kemudian dari kebutuhan gasnya dihitung berapa truk yang diperlukan, berapa kapal yang harus digunakan untuk mengangkutnya dan berapa investasi yang dibutuhkan ,IRR,NPV dan PBPnya Dalam kajian keekonomian akan digunakan permodelan matematis dan optimasi menggunakan bantuan solver dari microsoft excel.

Ruang lingkup kajian teknis yaitu dibatasi pada mini terminal di superbloknya seperti spesifikasi yang dibutuhkan dalam mini terminal LNG-nya, kemudian dengan menggunakan standar NFPA 59A dibuat tata letaknya serta dilakukan permodelan 3 dimensi dengan tools google sketch up

\section{ANALISIS DAN PEMBAHASAN}

\section{A. Kajian Ekonomi}

\section{1) Menghitung Permintaan Gas}

Menghitung permintaan gas dimulai dengan membuat daftar superblok-superblok yang berpotensi. Terdapat banyak pembangunan-pembangunan superblok yang tersebar di Jakarta dan sekitarnya. Permintaan gas dihitung dengan cara membagi banyaknya rumah/apartemen dengan tabel asumsi gas.

TABEL 1. ASUMSI KEBUTUHAN GAS YANG DIGUNAKAN

\begin{tabular}{cccccc}
\hline Komponen & Unit & $\begin{array}{c}\text { Permintaan } \\
\text { gas per } \\
\text { hari (m3) }\end{array}$ & $\begin{array}{c}\text { LNG } \\
\text { Demand } \\
\text { per hari } \\
(\mathrm{m} 3)\end{array}$ & $\begin{array}{c}\text { LNG } \\
\text { demand } \\
\text { per hari } \\
\text { (ton) }\end{array}$ & mmscfd \\
\hline Industri & 1 & 500 & 0.83 & 0.3818 & 0.01818 \\
\hline Komersial & 1 & 50 & 0.083 & 0.03818 & 0.001818 \\
\hline $\begin{array}{c}\text { Rumah } \\
\text { tangga }\end{array}$ & 250 & 292 & 0.4867 & 0.223882 & 0.01066 \\
\hline
\end{tabular}

Sumber : Ketut Buda Artana.2016 [8]

Dari daftar tadi dihitung jumlah kebutuhan gasnya berdasarkan jumlah rumah/apartemen dan area komersial yang berada di superblok tersebut. Berikut merupakan perhitungan kebutuhan gas harian dari superbloksuperblok di Jakarta dan sekitarnya.

TABEL 2. KeBUtUhAN GAS DI SUPERBLOK JADETABEK

\begin{tabular}{cccccccc}
\hline No & Nama & $\begin{array}{c}\text { Rumah } \\
\text { (unit) }\end{array}$ & $\begin{array}{c}\text { Apartemen } \\
\text { (unit) }\end{array}$ & $\begin{array}{c}\text { Komersial } \\
\text { (Area) }\end{array}$ & $\begin{array}{c}\text { rumah/ } \\
\text { apartemen }\end{array}$ & komersial & $\begin{array}{c}\text { Total } \\
\text { (mmscfd) }\end{array}$ \\
\hline 1 & Alam Sutera & 4500 & & 5 & 0.19188 & 0.009 & 0.2009 \\
\hline 2 & Bsd City & 2100 & & 5 & 0.089544 & 0.009 & 0.0985 \\
\hline 3 & $\begin{array}{c}\text { Bukit Golf } \\
\text { Mediterania }\end{array}$ & 2500 & & 3 & 0.1066 & 0.0054 & 0.1120 \\
\hline 4 & CBD Pluit & & 1736 & 2 & 0.074023 & 0.0036 & 0.0776 \\
\hline 5 & Ciputra World & 300 & 185 & 4 & 0.0206804 & 0.0072 & 0.0279 \\
\hline 6 & Gandaria City & & 600 & 4 & 0.025584 & 0.0072 & 0.0328 \\
\hline 7 & $\begin{array}{c}\text { Golf Lake } \\
\text { Residence }\end{array}$ & 1200 & & 2 & 0.051168 & 0.0036 & 0.0548 \\
\hline 8 & $\begin{array}{c}\text { Grand Galaxy } \\
\text { City }\end{array}$ & 1800 & & 2 & 0.076752 & 0.0036 & 0.0804 \\
\hline 9 & Grand Indonesia & & 263 & 3 & 0.0112143 & 0.0054 & 0.0166 \\
\hline & & & & & &
\end{tabular}

\begin{tabular}{cccccccc}
\hline 10 & Green lake city & 2000 & & 3 & 0.08528 & 0.0054 & 0.0907 \\
\hline 11 & Harapan Indah & 2000 & & 2 & 0.08528 & 0.0036 & 0.0889 \\
\hline 12 & Kelapa Gading & 2500 & 1000 & 5 & 0.14924 & 0.009 & 0.1582 \\
\hline 13 & Kemang Village & & 700 & 4 & 0.029848 & 0.0072 & 0.0370 \\
\hline 14 & Kota Kasablanka & & 300 & 3 & 0.012792 & 0.0054 & 0.0182 \\
\hline 15 & Kuningan City & & 600 & 3 & 0.025584 & 0.0054 & 0.0310 \\
\hline 16 & Lippo Karawaci & 1600 & & 3 & 0.068224 & 0.0054 & 0.0736 \\
\hline 17 & Podomoro City & & 5778 & 3 & 0.2463739 & 0.0054 & 0.2518 \\
\hline 18 & Puri Indah & 1500 & & 5 & 0.06396 & 0.009 & 0.0730 \\
\hline 19 & Puri Mansion & 500 & 500 & 2 & 0.04264 & 0.0036 & 0.0462 \\
\hline 20 & $\begin{array}{c}\text { Rasuna } \\
\text { Epicentrum }\end{array}$ & & 1440 & 3 & 0.0614016 & 0.0054 & 0.0668 \\
\hline 21 & $\begin{array}{c}\text { Summarecon } \\
\text { Bekasi }\end{array}$ & 1500 & & 3 & 0.06396 & 0.0054 & 0.0694 \\
\hline 22 & $\begin{array}{c}\text { Summarecon } \\
\text { Serpong }\end{array}$ & 10000 & & 5 & 0.4264 & 0.009 & 0.4354 \\
\hline & & Total Keseluruhan & & 2.1416 & \\
\hline
\end{tabular}

2) Menghitung jumlah Truk

Jumlah truk yang akan digunakan akan dicari dengan menggunakan rumus:

Banyaknya truk $=\frac{\text { total waktu seluruh perjalanan }}{\text { waktu yang ada untuk mengatar }}$

Langkah-langkah yang digunakan dalam menentukan jumlah truk dan tangki, membagi ukuran demand berdasarkan ISO Tanknya (20\&40feet), menentukan time horizon, menghitung jarak antara supply dan demandnya kemudian membagi banyaknya waktu yang dibutuhkan per trip dengan time horizon baru kemudian langkah terakhir menentukan banyak truk dengan rumus diatas.

TABEL 3. SUPERBLOK YANG AKAN MENGGUNAKAN ISO TANK 40FEET DENGAN TIME HORIZON 14 HARI

\begin{tabular}{|c|c|c|c|c|c|c|c|}
\hline No. & Nama & $\begin{array}{c}\text { Jarak / s } \\
(\mathrm{km})\end{array}$ & $\begin{array}{l}\text { Waktu/t } \\
\text { (menit) }\end{array}$ & roundtrip & unload & $\mathrm{n}$ trip & $t_{\text {total }} \cdot n$ \\
\hline 1 & Summarecon Serpong & 29 & 87 & 174 & 219 & 6 & 1314 \\
\hline 2 & Podomoro City & 23 & 69 & 138 & 183 & 4 & 732 \\
\hline 3 & Alam Sutera & 25 & 75 & 150 & 195 & 3 & 585 \\
\hline 4 & Kelapa Gading & 35 & 105 & 210 & 255 & 2 & 510 \\
\hline 5 & $\begin{array}{c}\text { Bukit Golf } \\
\text { Mediterania }\end{array}$ & 11 & 33 & 66 & 111 & 2 & 222 \\
\hline 6 & Bsd City & 40 & 120 & 240 & 285 & 1 & 285 \\
\hline 7 & Green lake city & 19 & 57 & 114 & 159 & 1 & 159 \\
\hline 8 & Harapan Indah & 42 & 126 & 252 & 297 & 1 & 297 \\
\hline 9 & Grand Galaxy City & 51 & 153 & 306 & 351 & 1 & 351 \\
\hline 10 & CBD Pluit & 16 & 48 & 96 & 141 & 1 & 141 \\
\hline 11 & Lippo Karawaci & 31 & 93 & 186 & 231 & 1 & 231 \\
\hline \multirow[t]{2}{*}{12} & Puri Indah & 17 & 51 & 102 & 147 & 1 & 147 \\
\hline & & & & \multicolumn{3}{|c|}{ total keseluruhan } & 4974 \\
\hline
\end{tabular}

TABEL 4. SUPERBLOK YANG AKAN MENGGUNAKAN ISO TANK 20FEET DENGAN TIME HORIZON 28 HARI

\begin{tabular}{cccccccc}
\hline No. & Nama & $\begin{array}{c}\text { jarak } / \mathrm{s} \\
(\mathrm{km})\end{array}$ & $\begin{array}{c}\text { waktu/t } \\
(\mathrm{m} \text { enit })\end{array}$ & roundtrip & unload & $\mathrm{n}$ trip & tout $\cdot \mathrm{n}$ \\
\hline 1 & Summarecon Bekasi & 50 & 150 & 300 & 345 & 5 & 1725 \\
\hline 2 & Rasuna Epicentrum & 31 & 93 & 186 & 231 & 4 & 924 \\
\hline 3 & Golf Lake Residence & 9 & 27 & 54 & 99 & 4 & 396 \\
\hline 4 & Puri Mansion & 16 & 48 & 96 & 141 & 3 & 423 \\
\hline 5 & Kemang Village & 31 & 93 & 186 & 231 & 3 & 693 \\
\hline 6 & Gandaria City & 27 & 81 & 162 & 207 & 2 & 414 \\
\hline 7 & Kuningan City & 30 & 90 & 180 & 225 & 2 & 450 \\
\hline 8 & Ciputra World & 28 & 84 & 168 & 213 & 2 & 426 \\
\hline 9 & Kota Kasablanka & 31 & 93 & 186 & 231 & 1 & 231 \\
\hline 10 & Grand Indonesia & 29 & 87 & 174 & 219 & 1 & 219 \\
\hline & & & total keseluruhan & 5901 \\
\hline
\end{tabular}

Truk yang dibutuhkan untuk melayani kebutuhan yang 40feet adalah

$$
\text { Banyaknya truk : } \frac{4974}{14 \times 7 \times 60}=0.8459
$$

Sedangkan untuk yang 20 feet adalah

$$
\text { Banyaknya truk : } \frac{5901}{28 \times 7 \times 60}=0.501
$$

Jadi truk yang dibutuhkan untuk mengantar ISO Tank LNG adalah masing-masing 1 untuk 20 dan 40 feet..

\section{3) Menghitung kapasitas terminal penerima dan kapal}

Kapasitas kapal dan terminal penerima sangat erat kaitannya, semakin besar kapasitas kapal maka frekuensi kapal dari FSRU menuju Terminal penerima akan semakin sedikit dan kapasitas penerima harus besar juga namun bila kapasitas kapal kecil maka frekuensi kapal akan sering. Dengan permintaan gas yang sudah dihitung 
yaitu sebesar 2.1416 MMSCF per harinya maka untuk menentukan kapasitas kapal dan terminal penerima akan digunakan Solver. Terdapat tiga hal penting dalam solver yaitu input,constraint/batasan dan objective function

Variabel-variabel yang digunakan dalam pengambilan keputusan (input) meliputi Capital Cost yaitu harga kapal dan fasilitas penerimanya. Operational Cost yaitu bahan bakar, gaji para ABK, asuransi kapal, biaya perawatan ,biaya administrasi

Batasan yang digunakan adalah jumlah kapasitas pengiriman dalam satu tahun yang harus dipenuhi. Sedangkan objective function nya adalah total biaya investasi yang paling rendah.

TABEL 5. HASIL OPTIMASI SOLVER

\begin{tabular}{|c|c|c|c|c|}
\hline \multicolumn{5}{|c|}{ CONSTRAINT } \\
\hline $\begin{array}{l}\text { DEMAND } \\
\text { PER YEAR }\end{array}$ & Min Value & $g(x)$ & $\begin{array}{c}\max \\
\text { value }\end{array}$ & unit \\
\hline $\begin{array}{l}\text { Receiving } \\
\text { terminal }\end{array}$ & 16789.5 & 24090 & 33579 & Ton / year \\
\hline \multicolumn{5}{|c|}{ OUTPUT } \\
\hline & & $\min$ & $g(x)$ & $\max$ \\
\hline $\begin{array}{l}\text { Number of } \\
\text { Ship Size } 1\end{array}$ & unit & 0 & 1 & 10 \\
\hline $\begin{array}{l}\text { Number of } \\
\text { Ship Size } 2\end{array}$ & unit & 0 & 0 & 10 \\
\hline $\begin{array}{l}\text { Number of } \\
\text { Ship Size } 3\end{array}$ & unit & 0 & 0 & 10 \\
\hline \multicolumn{5}{|c|}{ OBJECTIVE } \\
\hline $\begin{array}{c}\text { Total } \\
\text { investment }\end{array}$ & \multicolumn{4}{|c|}{$11,806,990.89$} \\
\hline
\end{tabular}

Hasil dari optimasi solvernya adalah terpilihnya kapal dengan kapasitas 1000m3, kapal yang kurang lebih panjangnya 65 meter.

4) Capex, Opex NPV,IRR dan Payback Period

Investasi yang dibutuhkan untuk pengadaan fasilitas (capital cost) adalah sebesar 19,070,000 US\$ biaya ini meliputi pengadaan kapal, terminal LNG, truk dan 22 terminal LNG pada superblok dengan rincian seperti pada tabel dibawah.

Sedangkan biaya operasional yang dibutuhkan adalah $1,666,436$ US\$ dengan rinciannya sebagai berikut:
TABEL 6. RINCIAN DARI CAPITAL COST

\begin{tabular}{ccc}
\hline INVESTTMENT & Unit & Value \\
\hline investment for receiving terminal & & \\
\hline Investment for LNG Carrier & US\$ & $5,000,000.00$ \\
\hline $\begin{array}{c}\text { Investment for terminal (jetty, } \\
\text { utilities, etc) }\end{array}$ & US\$ & $6,121,000.00$ \\
\hline $\begin{array}{c}\text { investment for each superblok } \\
\text { mini terminal }\end{array}$ & US\$ & $2,705,000.00$ \\
\hline truk & US\$ & $244,000.00$ \\
\hline Pipe & US\$ & $5.000,000.00$ \\
\hline TOTAL INVESTMENT US\$ & $19,070,000.00$ \\
\hline
\end{tabular}

TABEL 7. RINCIAN DARI BIAYA OPERSIONAL

\begin{tabular}{ccc}
\hline SHIP OPERATIONAL COST & Unit & Value \\
\hline $\begin{array}{c}\text { operational cost per year }(1 \mathrm{mini} \\
\text { 1000m3) }\end{array}$ & US\$-year & $685,990.00$ \\
\hline Operational days & days & 365.00 \\
\hline operational cost per days & US\$/days & $1,879.42$ \\
\hline TOTAL OPERATIONAL COST & US\$/YEAR & $685,990.00$ \\
\hline $\begin{array}{c}\text { RECEIVING TERMINAL } \\
\text { COST }\end{array}$ & Unit & Value \\
\hline $\begin{array}{c}\text { Power Requirement at Loading } \\
\text { terminal }\end{array}$ & KW & 400.00 \\
\hline $\begin{array}{c}\text { Power Requirement at all } \\
\text { superblok terminal }\end{array}$ & KW & 880.00 \\
\hline Total power requirement & KW & $1,280.00$ \\
\hline electricity rate & Rp/KWH & 768.00 \\
\hline electricity rate & US\$/KWH & 0.08 \\
\hline Annual electricity cost & US\$/tahun & $906,466.36$ \\
\hline annual maintenance cost & US\$/year & $60,466.67$ \\
\hline annual gasoline cost & US\$/year & $13,513.50$ \\
\hline TOTAL OPERATIONAL COST & US\$/year & $1,666,436.52$ \\
\hline
\end{tabular}

Pendapatan yang diterima merupakan perkalian antara jumlah gas yang dijual setiap tahunnya dikalikan dengan margin keuntungannya. Dengan jumlah gas yang dijual setiap tahunnya/gas yang di transportasikan sebanyak 781.800 MMBTU.

TABEL 8. PENDAPATAN DENGAN VARIASI MARGIN

\begin{tabular}{cc}
\hline \multicolumn{2}{c}{ REVENUE } \\
\hline MARGIN & ANNUAL \\
PROFIT & REVENUE \\
\hline 4 & $3,124,400.00$ \\
\hline 4.5 & $3,514,950.00$ \\
\hline 5 & $3,905,500.00$ \\
\hline 5.5 & $4,296,050.00$ \\
\hline 6 & $4,686,600.00$ \\
\hline
\end{tabular}

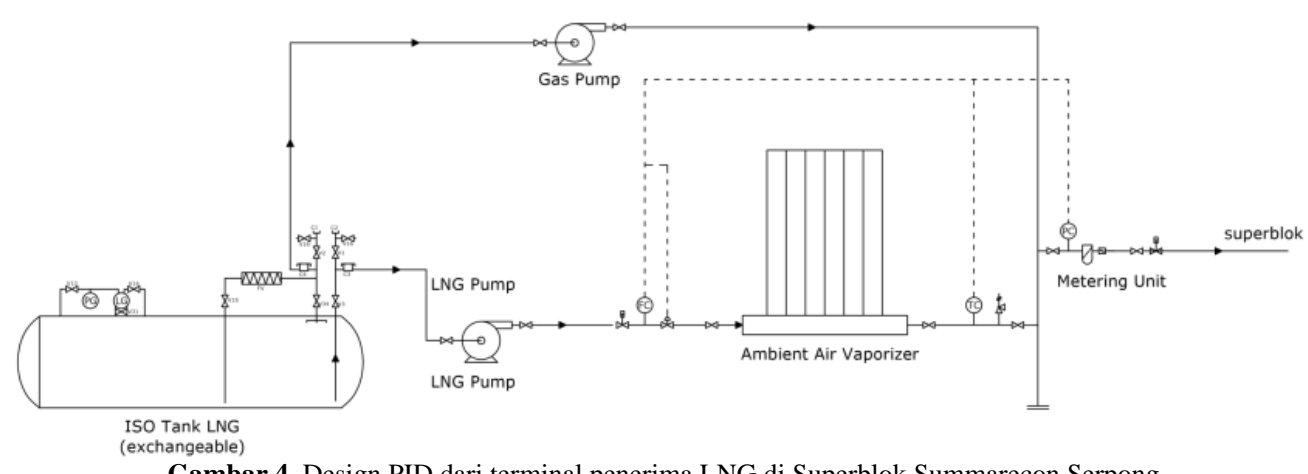

Gambar 4. Design PID dari terminal penerima LNG di Superblok Summarecon Serpong

Dengan biaya operasional sebesar 1,666,436.52 US\$/year maka investasi mulai layak apabila margin profit 4.5 US\$. Dengan margin profit 4.5 US\$, maka akan kembali modal pada tahun ke 12 bulan ke 3 degan return of Investment $8 \%$ sedangkan margin profit 5 US\$ akan kembali tahun ke 10 , bulan 7 dengan return of Investment 9\%.margin 5.5 US\$ pada tahun ke 9 bulan 2 dengan ROI $11 \%$ dan margin 6 US\$ pada tahun ke 8 dengan ROI $12 \%$
Menggunakan lifetime selama 15 tahun maka Net Present Value ,margin profit 6 pada tahun ke 15 adalah 5,001,253 US\$ (Interest Rate : 5\%) , 3,453,478 US\$ (Interest Rate : 6\%) dan 2,051,977 US\$ (Interest Rate : $7 \%$ ). Sedangkan NPV margin profit 4 tidak ada yang bernilai positif. 


\section{B. Kajian Teknis}

1) Spesifikasi teknis fasilitas penerima $L N G$ di Superblok Summarecon Serpong

Tangki sudah ditentukan sebelumnya yaitu yang akan digunakan berupa ISO Tank berukuran 40feet. Kemudian regasifikasi, terdapat 2 jenis regasifikasi yang cocok dengan kapasitas yang kecil yaitu Ambient air vaporizers $(A A V)$ dan Open Rack Vaporizers $(O R V)$. Namun mengingat dari lokasi superblok yang jauh dari laut maka hanya Ambient air vaporizers $(A A V)$ yang menjadi feasible. Dengan temperatur lingkungan rata-rata berkisar antara 23 - 32 derajat Celsius (weather.com)

TABel 9. PERHITUNGAN KEBUtUhAN UNIT REGASIFIKASI

\begin{tabular}{ccc}
\hline Regasification unit calculation & & \\
\hline Capacity required & 19.88 & $\mathrm{~m}^{3} / \mathrm{day}$ \\
\hline Capacity required & 0.83 & $\mathrm{~m}^{3} / \mathrm{hr}$ \\
\hline Operation time & 24 & $\mathrm{hr} / \mathrm{day}$ \\
\hline Vaporizer nominal capacity & 1.82 & $\mathrm{Nm}^{3} / \mathrm{hr}$ \\
\hline Required pressure & 15 & $\mathrm{bar}$ \\
\hline
\end{tabular}

Pompa akan digunakan untuk menyuplai LNG dari ISO Tank menuju Vaporizers. Pompa yang dipilih berdasarkan kapasitas dan tekanan yang dibutuhkan oleh vaporizers.

TABEL 10. PERHITUNGAN KEBUTUHAN POMPA

\begin{tabular}{ccc}
\hline \multicolumn{3}{c}{ Pump requirement } \\
Capacity required & 0.83 & $\mathrm{~m}^{3} / \mathrm{h}$ \\
\hline Pressure required to vaporizer $(\mathrm{Hp})$ & 15 & $\mathrm{bar}$ \\
\hline
\end{tabular}

2) PFD dan PID fasilitas penerima $L N G$ di Superblok Summarecon Serpong

Fasilitas penerima LNG baik itu untuk yang berskala kecil (mini) maupun yang umum terdiri dari komponen yang sama yaitu unloading, storage, pump dan regasifikasi. Namun pada skala kecil ini karena menggunakan ISO Tank yang mampu menahan BOG sampai dengan 26 hari maka tidak ada fasilitas untuk penanganan BOG dan recondenser. PFD atau diagram alir menjelaskan gambar skematik dari aliran LNG atau gas yang melalui setiap unit peralatan pada fasilitas penerima LNG di Superblok Summarecon Serpong.

Terminal penerima LNG di superblok didesain dengan sistem yang tergolong masih baru, dimana tangki didesain bukan untuk diisi ulang namun diganti setiap kali habis seperti mengganti tabung gas pada rumah-rumah. Jadi truk akan menurunkan tangki yang terisi penuh dan menukarnya dengan tangki yang kosong. Tangki pada terminal penerima ini menggunakan ISO Tank 40feet,dengan kapasitas $47 \mathrm{~m} 3$ maka akan Tangki ini telah dilengkapi dengan sambungan untuk pompa sehingga tangki tinggal disambungkan dengan pompa LNG untuk ditransfer menuju Ambient air vaporizer (AAV) untuk diubah bentuknya dari cair menuju gas. Baru setelah itu, gas siap didistribusikan menuju konsumen di superblok.

Dari Process flow diagram yang sudah dibuat kemudian dikembangkan menjadi piping and instrument diagram (gambar 4). ISO Tank dilengkapi dengan pressure gauge untuk mengetahui tekanan di dalam tangki dan level gauge untuk mengetahui seberapa banyak LNG tersisa. ISO Tank juga dilengkapi dengan vin vaporizer yang berfungsi apabila tekanan di dalam tangki meningkat.

3) Lay out dan perencanaan peletakan fasilitas penerima LNG di Superblok Summarecon Serpong

Berdasarkan dari luas tanah yang tersedia sekitar 50 meter x 100 meter maka digambarlah tata letak dari terminal penerima ini beserta gambar tiga dimensinya dengan menggunakan ukuran - ukuran asli dari fasilitas yang telah didapatkan dari pemilihan spesifikasi dan aturan NFPA 59A. Lahan yang dibutuhkan yaitu panjang 50 meter dan lebar 50 meter. Berikut merupakan tampilan tampak atas dan tiga dimensi dari fasilitas penerima.

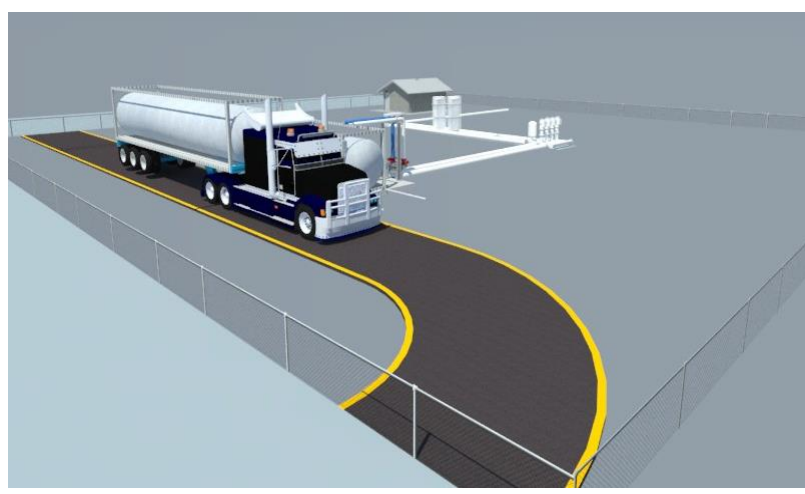

Gambar 6. Tampilan 3 dimensi dari terminal penerima LNG di Superblok Summarecon Serpong

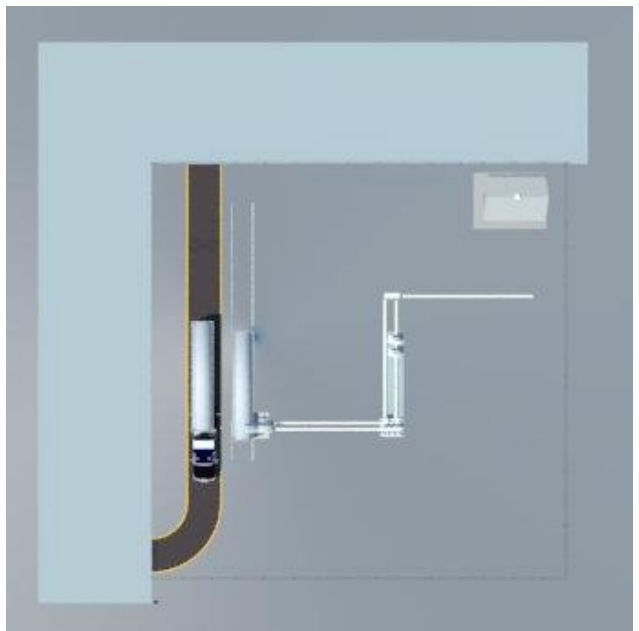

Gambar 7. Tampak atas dari terminal penerima LNG di Superblok Summarecon Serpong

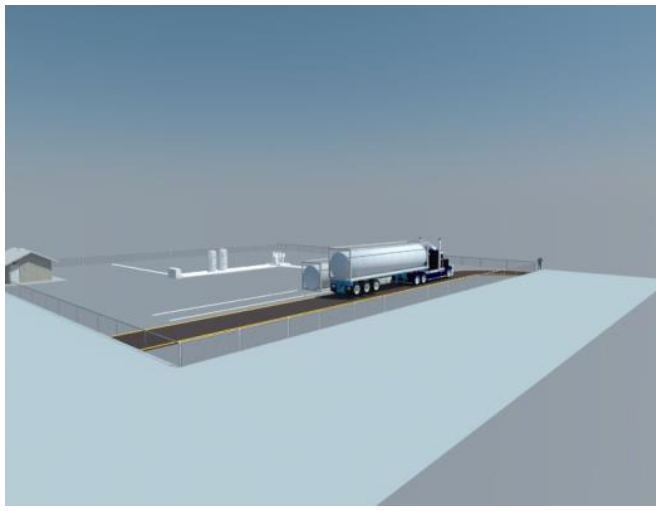

Gambar 8. Tampilan 3 dimensi dari terminal penerima LNG di Superblok Summarecon Serpong 


\section{KESIMPULAN}

Berdasarkan analisis dan pembahasan di atas, didapatkan kesimpulan sebagai berikut:

a) Kebutuhan gas pada 22 kawasan superblok di wilayah Jakarta dan sekitarnya kurang lebih 2.14 MMSCFD

b) NPV bernilai positif jika margin penjualan 6 US\$ jumlah LNG yang di transportasikan setiap tahunnya sebanyak 781.800 MMBTU. Dengan total nilai investasi yang dibutuhkan 19,070,000.00 US\$ dan biaya operasional sebesar $1,666,436.52$ US\$

c) LNG akan diangkut dari FSRU Jawa barat menuju terminal perantara menggunakan LNG self propelled barge dengan kapasitas $1000 \mathrm{~m}^{3}$ kemudian dari terminal perantara akan didistribusikan lagi ke superblok menggunakan ISO Tank LNG yang diangkut oleh masingmasing 1 truk untuk 20feet dan 40feet.

d) Luas tanah yang dibutuhkan untuk membuat mini terminal LNG adalah 50 x 50 meter. Layoutnya berisi fasilitas regasifikasi , pompa dan tangki ISO Tank yang dapat diganti

\section{DAFTAR PUSTAKA}

[1] Badan Pengkajian dan Penerapan Teknologi. (2014). Outlook Energi Indonesia.

[2] (2015, Oktober 30). Retrieved from Kontan: http://industri.kontan.co.id/news/pgn-salurkan-gas-bumi-ke137-kk-di-pasuruan

[3] (2015, November 7). Retrieved from Kontan http://industri.kontan.co.id/news/fsru-teluk-jakarta-akhirnyaberoperasi

[4] Soegiono, \& Artana, K. B. (2006). Transportasi LNG Indonesia. Surabaya: UNAIR Press.

[5] International Gas Union. (2014). World LNG Report

[6] Kamil, R. (2015, December 28). https://ridwankamil.wordpress.com.

[7] NFPA 59A: Standard for the Production, Storage, and Handling of Liquefied Natural Gas (LNG). (n.d.).

[8] Fakultas Teknologi Kelautan ITS. "Model Cluster Distribusi LNG", Kerja sama ITS-PGN.

[9] [9] NS, Y. O., DP, A. D., \& Artana, K. B. (n.d.). Distribusi Gas Alam Cair (LNG) dari Kilang Menuju. Digilib ITS.

[10] ITS. (n.d.). Model Cluster Distribusi LNG for PGN. 